\title{
Enhancing Students' Motivation and Problem Solving Skills in Mathematics Using Guided Discovery Learning
}

\author{
Tanti Diyah Rahmawati ${ }^{1}$, Dwi Sulisworo ${ }^{2, *}$, Erwin Prasetyo ${ }^{3}$ \\ ${ }^{1}$ Department of Mathematics Education, IKIP Muhammadiyah Maumere, Sikka, Indonesia \\ ${ }^{2}$ Department of Physics Education, Ahmad Dahlan University, Yogyakarta, Indonesia \\ ${ }^{3}$ Department of Physics Education, IKIP Muhammadiyah Maumere, Sikka, Indonesia
}

Received August 13, 2020; Revised August 17, 2020; Accepted November 12, 2020

\section{Cite This Paper in the following Citation Styles}

(a): [1] Tanti Diyah Rahmawati, Dwi Sulisworo, Erwin Prasetyo, "Enhancing Students' Motivation and Problem Solving Skills in Mathematics Using Guided Discovery Learning, "Universal Journal of Educational Research, Vol. 8, No. 12, pp. 6783 - 6789, 2020. DOI: 10.13189/ujer.2020.081244.

(b): Tanti Diyah Rahmawati, Dwi Sulisworo, Erwin Prasetyo (2020). Enhancing Students' Motivation and Problem Solving Skills in Mathematics Using Guided Discovery Learning. Universal Journal of Educational Research, 8(12), 6783 - 6789. DOI: 10.13189/ujer.2020.081244.

Copyright $\mathrm{C} 2020$ by authors, all rights reserved. Authors agree that this article remains permanently open access under the terms of the Creative Commons Attribution License 4.0 International License

\begin{abstract}
Guided discovery learning is one of the learning models that focus on students. This model is one of the recommended models for implementing the 2013 Curriculum as a foundation for education reform in Indonesia. It's just that the internalization of teachers in the learning models that focus on students still needs to be improved. This study aims to see the impact of guided discovery learning on motivation and problem-solving abilities. This research is a descriptive quantitative study conducted on exponential mathematics subject topics and logarithms in class 10 in Maumere, Nusa Tenggara Timur, Indonesia. The student motivation data was collected using a questionnaire consisting of 40 items and measured using a Likert scale of 1 to 5 . The problem-solving ability was measured using 5 test items. Assessment of the answer questions with a score of 0 to 4 for each aspect of problem-solving ability (understanding, planning, completing, rechecking). Descriptive statistics were used to prose the data. The results of this paper indicate that the motivation of students who get learning with this strategy is high. Although students, in general, have done other problem-solving activities well on the aspects of Understanding the problem, compiling a plan of the resolution, implementing a method of recommendation, but in the aspect of Rechecking at the suitability of the results tends not to be done well. The impact of this finding is the possibility of thinking habits that still need to be improved in the problem-solving process.
\end{abstract}

Keywords Learning Motivation, Problem-Solving
Ability, Mathematics, Guided Discovery, Learning Strategy, Learning Environment, Learning Innovation, Learning Satisfaction

\section{Introduction}

The 2013 Curriculum is a curriculum development strategy to create an effective, productive, and outstanding school. The 2013 Curriculum considered became a new paradigm of curriculum development that gives students the broadest opportunity to express, think, and innovate. The teacher's role is to provide motivation and direct the learning process to students. In the learning process at school, the teacher plays a crucial role in the achievement of a good learning process. The main task of the teacher in learning activities at school is to create an atmosphere of teaching and learning that can motivate students always to learn optimally. Motivation is an essential factor in learning [1,2]. Good motivation encourages students to develop various aspects of learning performance. Various learning strategies are developed by educators and researchers to be able to provide a learning environment that encourages higher motivation $[3,4]$, including achieving mathematics learning outcomes $[5,6]$. Therefore, researchers are interested in seeing motivation and problem-solving abilities using a guided discovery learning model. 
Motivation to learn is a drive from within a person to make changes that are marked by the emergence of feelings and reactions to achieve goals. Motivation to learn is also a need to develop self-abilities optimally so that they can do better, excel, and be creative [2,7]. Learning motivation encourages students to learn happily and learn seriously, which forms a way of teaching students that are systematic, full of concentration, and able to select their activities [7].

The indicators of learning motivation are diligent in doing the task, resilient in facing difficulties, interested in learning, eager to work independently, not easily bored with routine tasks, able to defend opinions, not easily let go of things that they believed, happy to find and solve problem problems $[4,7]$. Teachers have an essential role in learning to support student motivation with learning strategies [8]. Emotions and motivations contribute to mathematics education [9]. The researcher examines the impact of various strategies for achieving this $[10,11]$, including the application of guided inquiry $[12,13]$.

Problem-solving skills are the ability to solve problems, especially in ill-defined problems or non-routine problems [14]. This ability describes how an individual understands a problem, looks for alternative solutions, plans a solution, resolves, and confirms the solution obtained [15]. In various studies, problem-solving is firm to science process skills $[16,17]$. Besides, in learning mathematics, these skills can be built into an internalized habit in students through guided inquiry strategies $[15,18]$.

From this reason, learning motivation is an encouragement that causes an individual to act or act to achieve goals, to get a better chance. Learning motivation can affect learning outcomes, while student learning outcomes shown from students' problem-solving abilities in solving problems include national exam questions. National exam scores from year to year in mathematics are deficient. Data obtained from the National Education Standards Agency on the results of the 2015/2016 national exam, the average mathematics scores of students' participant school (a certain public junior high school) student in 2016 with 331 students, consisting of 58 students majoring in language, 98 students majoring in natural sciences and 175 students majoring in social studies are 33.13 in Major of Language, 21.42 in Major of Natural Sciences and 42.23 in Major of Social Sciences. Based on these data, the student learning outcomes are not satisfactory and are still below average.

Student learning outcomes are available from the ability of problem-solving. One of the things to improve the ability to solve is through a guided discovery learning model. Besides, the 2013 Curriculum demands are curriculum development strategies to create effective, productive, and outstanding schools. Thus, the habit of students doing functional problem-solving abilities to improve student learning outcomes.

Following the national education goals, problem-solving abilities are essential learning outcomes, and various research shows that guided inquiry strategy has the potential to increase that ability. A study of this learning strategy for increasing problem-solving skills in mathematics learning can have an impact on student progress. Thus, the purpose of this study is to increase motivation and problem-solving skills with guided inquiry learning strategies.

\section{Methods}

\subsection{Research Design}

This study uses descriptive quantitative methods conducted at public secondary schools in Maumere, Nusa Tenggara Timur, Indonesia. This region is a region with low HDI (human development index) levels compared to the other area in Indonesia [19]. Besides being a separate island territory. Subjects in this study were 10th-grade students, amounting to 39 students ( 15 males, 34 females). The subject matter applied is mathematics, which includes simple algebraic functions.

\subsection{Instruments}

There are some aspects that are included in the student learning motivation questionnaire. The first aspects of diligent in doing the task (5 items), resilient in facing difficulties (5 items), interested in learning (5 items), eager to work independently ( 5 items), not easily bored with routine tasks (5 items), able to defend opinions (5 items), not easily let go of things that they believed (5 items), happy to find and solve problem problems (5 items). The questionnaire was measured using a Likert scale from 1 (Strongly Disagree) to 5 (Strongly Agree), without a value of 3 (Neutral), and included 26 positive statements and 14 negative statements.

This paper uses the Polya theory to solve problems. It sets out four steps to make the students more focused on solving mathematical problems, namely understanding the problem, making plans, carrying out projects, and reviewing the results obtained. In its application, Polya's steps do not stand alone in classroom learning activities, but rather are part of a learning activity.

The indicators of mathematical problem-solving ability, namely: understanding the problem, drawing up a plan, implementing the program, and rechecking. Students' problem-solving abilities measured use tests derived from essential competencies in this learning that is understanding and analyzing various exponential and logarithms concepts and principles while using them in problem-solving.

The indicators used in measuring the ability to solve this problem are Understanding the problem (5 issues), Compiling a plan of resolution (5 items), Implementing a method of recommendation ( 5 points), Rechecking at the suitability of the results ( 5 problems). Test results assessed with socre of $0,1,2,3$ or 4 as in Table 1 . 
Table 1. Guidelines for problem-solving abilities

\begin{tabular}{ccc}
\hline Indicators & Response to problems & Score \\
\hline Understanding the problem & Do not understand the problem / no answer & 0 \\
\hline & Understand the problem well & 1 \\
\hline tompling a plan of resolution & There is no planned completion strategy & 2 \\
\hline & The planned strategy is not appropriate & 0 \\
\hline Use one specific strategy but lead to the wrong answer & 1 \\
\hline Use one specific strategy but cannot continue & 2 \\
\hline Use some correct strategies and lead to the right answer & 3 \\
\hline Thing the problem & There is a solution, but the procedure is not clear & 4 \\
\hline Use one particular procedure and lead to the right answer & 0 \\
\hline Use one particular procedure that is right but wrong in counting & 1 \\
\hline Use one particular procedure that is correct, and results are correct & 3 \\
\hline There is no answer check & 4 \\
\hline & Check only on answers (calculation) & 0 \\
\hline Check only on the process & 1 \\
\hline & Check on the process and answers & 2 \\
\hline
\end{tabular}

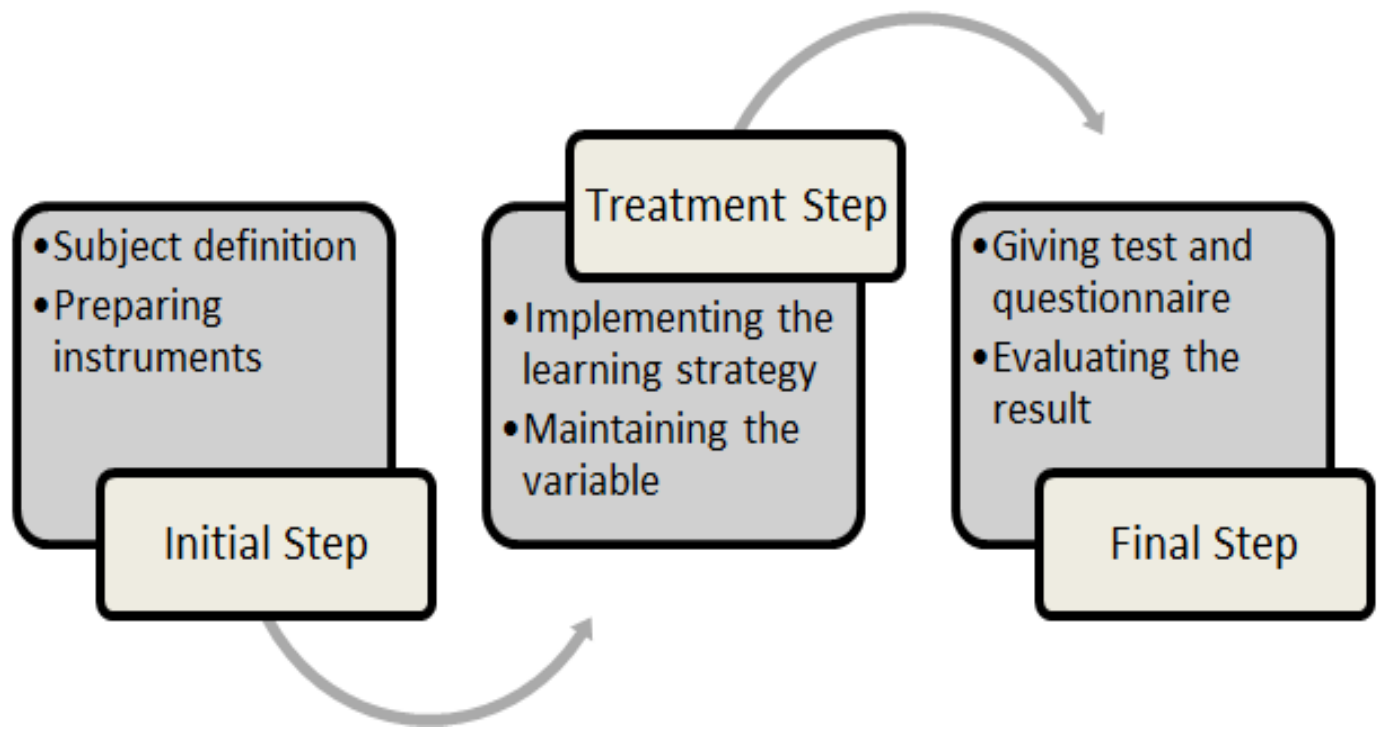

Figure 1. Research steps

\subsection{Research Steps}

There were three steps in this research, namely Initial Step, Treatment Step, and Final Step. At the initial step, the activities were to determine the subject of the study and the instrument's preparation for delivery through guided discovery learning strategies. At the treatment step, researchers, through the classroom-teacher, conducted learning following the research design. At this step, research instruments related to learning strategies are applied to build problem-solving skills. In the final step, researchers measured the impact of learning, especially on motivation and learning outcomes. These results become the material of research evaluation and analysis. Figure 1 shows the step of this research.

\subsection{Data Analysis Technique}

The data analysis technique used to calculate learning motivation scores is to use each item's percentage in the motivation questionnaire. These results are then averaged for all students and are confirmed using Table 2. 
Table 2. Conversion of motivational score ranges

\begin{tabular}{cc}
\hline Percent & Interpretation \\
\hline $\mathrm{x}<20 \%$ & Very low \\
\hline $20 \% \leq \mathrm{x}<40 \%$ & Low \\
\hline $40 \% \leq \mathrm{x}<60 \%$ & Enough \\
\hline $60 \% \leq \mathrm{x}<80 \%$ & High \\
\hline $\mathrm{x} \geq 80 \%$ & Very high \\
\hline
\end{tabular}

Scoring guidelines for problem-solving abilities as measured by tests shown in Table 1 . Whereas classically, the consideration to have completed learning if it reaches $80 \%$ of the number of students who attain a minimum passing grade of 75 .

\section{Result}

As mentioned in the method section, there are three stages in this study: the initial step, the treatment step, and the final step. In the initial step the research subject has been defined. In this study, the research subjects were 10th-grade students consisting of 15 boys and 34 girls. The number of students before and an application of learning did not change. All students follow the learning process in full. Thus there was no subject mortality during the study. The purpose of this step was to maintain internal validity.

The instrument for measuring the problem-solving ability was developed with the Polya concept, which is following Table 1. The example of problem-solving problems is shown in Figure 2. From this figure, the problem is following the Polya concept. The red sentence was the teacher feedback completing the problem solving process. By what has been written in the method section, these questions are in several packages of items used for Quiz 1, Quiz 2, and Final exams. By looking at changes in scores from each stage of this measurement, students' progress in problem-solving skills can be observed. In the final step, students were given a final test and motivation questionnaire. The results of these two activities form the basis of analysis for the effectiveness of this learning strategy.

The results of learning motivation are shown in Table 3. The table shows that students' motivation towards learning during the trial met proper criteria. A high percentage (85.39) shows that students' learning motivation using guided discoveries and scientific approaches achieve the right standards.

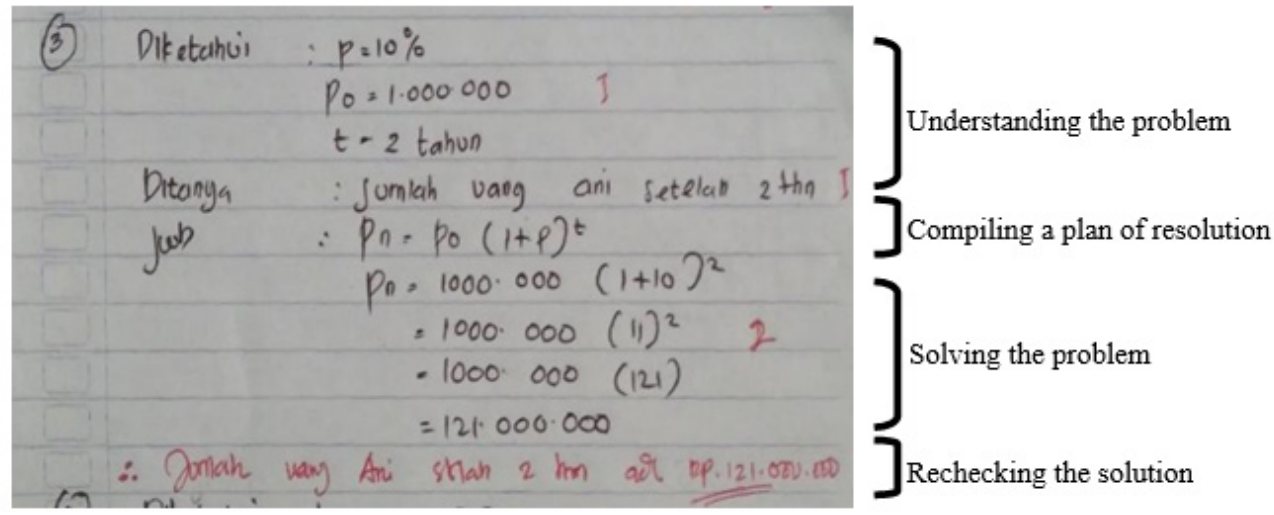

Figure 2. The example of problem solving ability test scoring based on Polya's concept

Table 3. Motivational score result

\begin{tabular}{|c|c|c|c|c|c|c|}
\hline \multirow{2}{*}{ No } & \multirow{2}{*}{ Indicators } & \multicolumn{4}{|c|}{ Responses (\%) } & \multirow{2}{*}{$\begin{array}{c}(\mathrm{A}+\mathrm{SA}) \\
\%\end{array}$} \\
\hline & & SA & A & $\mathrm{D}$ & SD & \\
\hline 1 & Diligent in doing the task (5 items) & 42.08 & 43.58 & 11.28 & 3.06 & 85.66 \\
\hline 2 & Resilient in facing difficulties (5 items) & 56.92 & 37.44 & 6.68 & 1.04 & 94.36 \\
\hline 3 & Interested in learning (5 items) & 35.88 & 51.28 & 11.28 & 1.56 & 87.16 \\
\hline 4 & Eager to work independently ( 5 items) & 34.38 & 52.84 & 11.30 & 1.48 & 87.22 \\
\hline 5 & Not easily bored with routine tasks ( 5 items) & 37.94 & 55.9 & 4.62 & 1.54 & 93.84 \\
\hline 6 & Able to defend opinions ( 5 items) & 22.56 & 51.57 & 22.56 & 3.31 & 74.34 \\
\hline 7 & Not easily let go of things that they believed (5 items) & 30.28 & 54.34 & 11.82 & 3.56 & 84.62 \\
\hline 8 & Happy to find and solve problem problems ( 5 items) & 26.66 & 49.24 & 16.40 & 7.70 & 75.9 \\
\hline \multicolumn{6}{|c|}{ Average } & 85.39 \\
\hline \multicolumn{7}{|c|}{ Category: Very high } \\
\hline
\end{tabular}




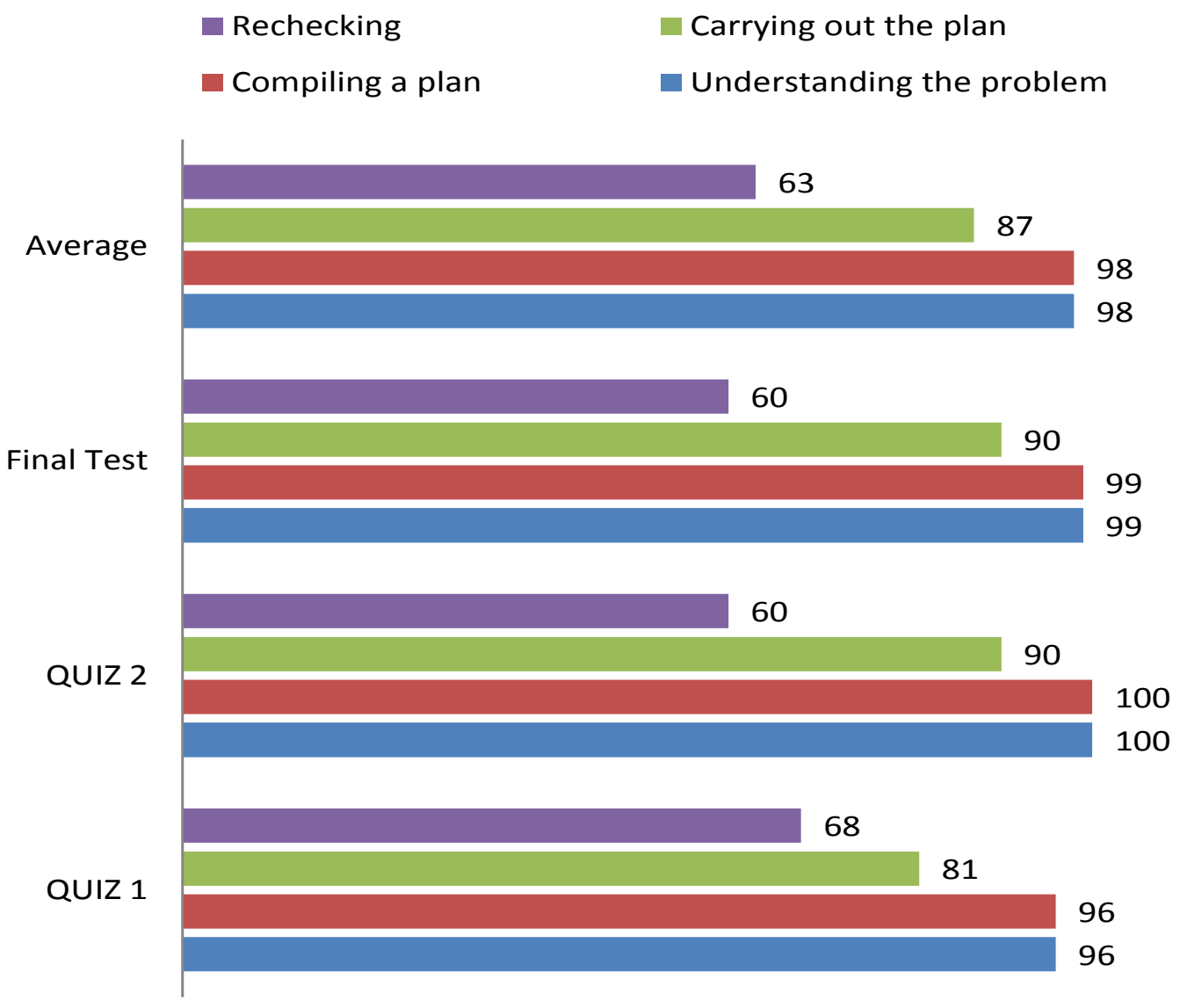

Figure 3. The Comparison of Problem Solving Abilities

The results of the problem-solving ability are showed in Figure 3. During the treatment of learning, students got three times the measurement of problem-solving skills; Quiz 1, Quiz 2, and Final Test.

\section{Discussion}

Based on the results of the overall problem ability test, the average score of students' understanding the problem is 98 , students can compile a plan is 98 , students can carry out problem-solving is 87 , and students' ability to recheck is 63 . Figure 2 shows that more and more stages decrease the average value. Because the majority of students can understand the problem, but when carrying out the problem-solving process, they tend to forget that mistakes are made in arithmetic and inaccurate. So students do not get maximum results when the last stage is rechecking the results of the answers. While students' learning motivation uses guided discoveries and scientific approaches with an average value of 85.39 , which includes the category of very agree and like to use guided discovery methods and scientific approaches.

The finding shows that students' learning motivation has increased using guided discovery or inquiry learning strategies. Increased learning motivation in guided discovery is higher than conventional. The results of the questionnaire analysis data of prior motivation and final motivation of students distributed in several categories in the research showed that students' learning motivation on guided discovery learning strategies was better than conventional learning strategies. It can be seen from the number of students who are included in the very high category $(52.63 \%)$ are more significant than in conventional learning strategies (8.1\%). Both classes have an initial motivation level in the same category, namely the high category with an average score of $62.46 \%$ in the class with conventional learning strategies and $62.32 \%$ in the course with the guided discovery strategy. Likewise, the final motivation level in the classroom with the guided discovery learning strategy $(78.08 \%)$ is higher than the average final motivation in the class with conventional learning strategies $(70.92 \%)$, but still in the same the top category.

When compared between the two learning strategies, the increase in all motivational indicators in the learning strategy of guided discovery is higher than the conventional learning strategy. Students' learning motivation in guided discovery learning strategies is better than conventional learning strategies $[20,21]$. There are 
significant differences in the mathematical performance of students taught using discovery learning strategies compared to being taught using nondiscovery strategies. The discovery model improved students' understanding of mathematical concepts and critical thinking abilities [22]. With an average achievement of each experiment, from 77.92 increasing to 81.81 . The process of answering students' answers to solve problems about concepts of understanding and critical thinking mathematical abilities of students with models for which guided discovery is more varied and better. Using guided discovery, students can gradually develop their abilities in solving problems [23]. Gradual guidance or scaffolding can improve student performance [17, 24, 25], not only on motivation but also in self-regulated learning [26, 27].

It needs to get attention because mathematical material and thinking are two inseparable things. Students must be able to connect ideas to understand mathematics, so they can use mathematical models to solve given problems; in other words, mathematics learning must able to be in high order or critical thinking $[11,13,16]$.

In this study, there are limitations to student-centered learning. Essential aspects of collaboration in knowledge have not yet been considered. Collaboration is a critical skill and should be maintained in learning $[28,29]$. On the other hand, the technology believed by educators to contribute to 21st-century learning has also not been studied constructively $[4,19,30]$. These limitations become a new basis for further research.

\section{Conclusion}

Based on the results of calculations and discussions of student learning motivation using guided discoveries and scientific approaches, it can be concluded that with this strategy students increase their learning motivation. In addition, this strategy can also improve students' abilities in problem solving. Right motivation and problem-solving abilities can be used to predict the student's learning outcomes. The impact of this learning is how teachers can apply various mathematical materials so that together they can improve students' learning performance.

\section{Acknowledgements}

SMAN 2 Maumere is permitted to make the school a place of research. This research is part of a research collaboration program between IKIP Muh Maumere and Ahmad Dahlan University.

\section{REFERENCES}

[1] Mayer, R. E. (1998). Cognitive, metacognitive, and motivational aspects of problem solving. Instructional science, 26(1-2), 49-63.
[2] Mayer, R. E. (2001). Cognitive, metacognitive, and motivational aspects of problem solving. In Metacognition in learning and instruction (pp. 87-101). Springer, Dordrecht.

[3] Sulisworo, D., Sulistyo, E. N., \& Akhsan, R. N. (2017). The Motivation Impact of Open Educational Resources Utilization on Physics Learning Using Quipper School App. Turkish Online Journal of Distance Education, 18(4), 120-128.

[4] Hwang, G. J., Hung, C. M., \& Chen, N. S. (2014). Improving learning achievements, motivations and problem-solving skills through a peer assessment-based game development approach. Educational Technology Research and Development, 62(2), 129-145.

[5] Mercader, J., Miranda, A., Presentación, M. J., Siegenthaler, R., \& Rosel, J. F. (2018). Contributions of motivation, early numeracy skills, and executive functioning to mathematical performance. A longitudinal study. Frontiers in psychology, $8,2375$.

[6] Özcan, Z. Ç. (2016). The relationship between mathematical problem-solving skills and self-regulated learning through homework behaviours, motivation, and metacognition. International Journal of Mathematical Education in Science and Technology, 47(3), 408-420.

[7] Ashcraft, M. H. (2019). Cognitive and Motivational Underpinnings of Mathematical Learning Difficulties: A Discussion. In International Handbook of Mathematical Learning Difficulties (pp. 505-518). Springer, Cham.

[8] Yu, R., \& Singh, K. (2018). Teacher support, instructional practices, student motivation, and mathematics achievement in high school. The Journal of Educational Research, 111(1), 81-94.

[9] Schukajlow, S., Rakoczy, K., \& Pekrun, R. (2017). Emotions and motivation in mathematics education: theoretical considerations and empirical contributions. ZDM, 49(3), 307-322.

[10] Huda, W. N., Suyitno, H., \& Wiyanto, W. (2017). Analysis of Mathematical Problem Solving Abilities in Terms of Students' Motivation and Learning Styles. Journal of Primary Education, 6(3), 209-217.

[11] Tee, K. N., Leong, K. E., \& Rahim, S. S. A. (2018). The Mediating Effects of Critical Thinking Skills on Motivation Factors for Mathematical Reasoning Ability. The Asia-Pacific Education Researcher, 27(5), 373-382.

[12] Tornee, N., Bunterm, T., Lee, K., Muchimapura, S.. (2019). Examining the effectiveness of guided inquiry with problem-solving process and cognitive function training in a high school chemistry course. Pedagogies, 14 (2), pp. 126-149.

[13] Blumer, L.S., Beck, C.W. (2019). Laboratory courses with guided-inquiry modules improve scientific reasoning and experimental design skills for the least-prepared undergraduate students. CBE Life Sciences Education, 18 (1), art. no. ar2

[14] Zamakhsyari, Rahayu, S. (2020). Fostering ill-structured problem-solving skills of chemistry students using socioscientific issues as learning contexts. AIP Conference Proceedings, 2215, art. no. 020027 , 
[15] Sin, Y.W., Sihes, A.J., Hamidon, M. (2020. A review of problem-solving skills in mathematics and cooperative learning among primary school students. International Journal of Psychosocial Rehabilitation, 24 (5), pp. 605-613.

[16] Nworgu, L. N., \& Otum, V. V. (2013). Effect of guided inquiry with analogy instructional strategy on students acquisition of science process skills. Journal Education and Practice 4,(27) 35, 40.

[17] Prastiwi, D., Haryani, S. H. S., \& Lisdiana, L. (2018). The Effectiveness of Guided Inquiry with Mind Mapping to Improve Science Process Skills and Learning Motivation. Journal of Primary Education, 7(2), 195-203.

[18] Şen, Ş., Yılmaz, A., \& Geban, Ö. (2015). The effects of process oriented guided inquiry learning environment on students' self-regulated learning skills. Problems of Education in the 21st Century, 66, 54-66.

[19] Sulisworo, D., Kusumaningtyas, D.A., Anomeisa, A.B., Wahyuningsih, Rahmadhani, W. (2020). Perceptions of online learning experiences between students in urban and remote areas: Case study in indonesia. International Journal of Scientific and Technology Research, 9 (2), pp. $4850-4854$

[20] Scalise, K., Clarke-Midura, J. (2018). The many faces of scientific inquiry: Effectively measuring what students do and not only what they say. Journal of Research in Science Teaching, 55 (10), pp. 1469-1496.

[21] Scott, D.M., Smith, C.W., Chu, M.-W., Friesen, S. (2018). Examining the efficacy of inquiry-based approaches to education. Alberta Journal of Educational Research, 64 (1), pp. 35-54.

[22] Putra, M. I. S., Widodo, W., \& Jatmiko, B. (2016). The development of guided inquiry science learning materials to improve science literacy skill of prospective mi teachers. Jurnal Pendidikan IPA Indonesia, 5(1), 83-93.
[23] Trevathan, J., Gray, H., \& Myers, T. (2014). Scaling-up process-oriented guided inquiry learning techniques for teaching large information systems courses. Journal of learning design, 7, 23-38.

[24] Großmann, N., Wilde, M. (2019). Experimentation in biology lessons: guided discovery through incremental scaffolds. International Journal of Science Education, 41 (6), pp. 759-781.

[25] Sadeh, I., \& Zion, M. (2012). Which type of inquiry project do high school biology students prefer: Open or guided? Research in Science Education, 42(5), 831-848.

[26] English, M. C., \& Kitsantas, A. (2013). Supporting student self-regulated learning in problem-and project-based learning. Interdisciplinary journal of problem-based learning, $7(2), 6$.

[27] Mohamed, A. R. (2008). Effects of Active Learning Variants on Student Performance and Learning Perceptions. International Journal for the Scholarship of Teaching and Learning, 2(2), n2.

[28] Fadila, A., Septiana, A., Amelia, V., \& Wahyuni, T. (2019, February). The Influence of Group Investigation Learning Implementation Judging From Learning Motivation Against Students' Mathematical Problem Solving Ability. In Journal of Physics: Conference Series (Vol. 1155, No. 1, p. 012098). IOP Publishing.

[29] Chen, L., Inoue, K., Goda, Y., Okubo, F., Taniguchi, Y., Oi, M., Konomi, S., Ogata, H., Yamada, M. (2020). Exploring Factors that Influence Collaborative Problem Solving Awareness in Science Education. Technology, Knowledge and Learning, 25 (2), pp. 337-366.

[30] Gokhale, A., MaChina, K. (2018). Guided online group discussion enhances student critical thinking skills. International Journal on E-Learning: Corporate, Government, Healthcare, and Higher Education, 17 (2), pp. 157-173. 